\title{
Pelatihan Pengelolaan Sampah Rumah Tangga di Desa Pematang Johar, Deli Serdang
}

\author{
Mujahiddin*1, Yurisna Tanjung², Sahran Saputra ${ }^{3}$ \\ 1,2,3Program Stui Kesejahteraan Sosial, Fakultas Ilmu Sosial Ilmu Politik, \\ Universitas Muhammadiyah Sumatera Utara \\ *e-mail: mujahiddin@umsu.ac.id ${ }^{1}$
}

\begin{abstract}
The implementation of the Community Partnership Program (PKM) was carried out in Pematang Johar Village. This village was chosen because the waste management activities still use the Kumpul-AngkutDispose system. In addition, it is still a community member who manages waste by completing receiving waste, This PKM is carried out by providing training on waste management to the people in Pematang Johar Village. The method in this PKM activity is carried out with two approaches namely; socialization, training and FGD. The results of the PKM implementation show that: community group consisting of PKK Group and BUMDes Management Group have understood the practice of household scale waste management using the 3-R Principle. In addition, community groups have understood and are able to practice organic waste management into compost through the composter method. Community groups also understand and are able to practice inorganic waste management into creative goods such as piggy banks.
\end{abstract}

Keywords: Household and Waste Management Training

\begin{abstract}
Abstrak
Pelaksanaan Program Kemitraan Masyarakat (PKM) ini dilaksanakan di Desa Pematang Johar. Desa ini dipilih karena aktifitas pengelolaan sampah masih menggunakan sistem Kumpul-Angkut-Buang. Selain itu, masih terdapat warga masyarakat yang mengelola sampah dengan cara membakar tumpukan sampah. PKM ini dilaksanakan dengan memberikan pelatihan pengelolaan sampah kepada masyarakat yang ada di Desa Pematang Johar. Metode pada kegiatan PKM ini dilaksanakan dengan dua pendekatan yaitu; sosialisasi, pelatihan dan FGD. Hasil pelaksanaan PKM menunjukkan bahwa: Kelompok masyarakat yang terdiri dari Kelompok PKK dan Kelompok Pengurus BUMDes telah memahami praktik pengelolaan sampah skala rumah tangga dengan menggunakan Prinsip 3-R. Selain itu, kelompok masyarakat telah memahami dan mampu mempraktikkan pengelolaan sampah organik menjadi pupuk kompos melalui metode komposter. Kelompok masyarakat juga memahami dan mampu mempraktikkan pengelolaan sampah anorganik menjadi barang kreasi seperti celengan.
\end{abstract}

Kata kunci: Rumah Tangga dan Pelatihan Pengelolaan Sampah

\section{PENDAHULUAN}

Sampah masih menjadi satu permasalahan yang belum dapat diselesaikan hingga saat ini. Pada laporan Statistik Lingkungan Hidup Indonesia 2018 yang dikeluarkan oleh Badan Pusat Statistik (BPS) terkait Pengelolaan Sampah di Indonesia dijelaskan bahwa pada tahun 2016 lalu jumlah tibulan sampah di Indonesia mencapai 65,2 juta ton pertahun dengan jumlah penduduk sebanyak 261.115.456 orang. Jumlah tersebut pada tahun 2019 diperkirakan akan meningkat menjadi 66 sampai dengan 67 juta ton pertahun (Sulistya, 2019). Pertumbuhan jumlah penduduk menjadi salah satu variabel yang memberikan pengaruh terhadap pertumbuhan sampah di satu wilayah, selain variabel keadaan sosial-ekonomi dan kemajuan teknologi (Sasmita, 2009). Mujahiddin (2014) misalnya memberikan contoh keterkaitan antara pertumbuhan jumlah penduduk dengan peningkatan produksi sampah di Kota Medan sepanjang tahun 2009 hingga 2012. Dalam analisisnya terlihat ketika terjadi penurunan penduduk dari 2.121 .053 pada tahun 2009 menjadi 2.097 .610 pada tahun 2010 ternyata berdampak pada turunnya jumlah sampah pada tahun 2011 menjadi 1270,3344 ton yang pada tahun 2010 berjumlah 1292,99 ton. Ini berarti terjadi penurunan jumlah sampah sebesar 22,6556. Selanjutnya pada tahun 2011 ketika jumlah penduduk kembali naik menjadi 2.117.224 maka jumlah sampah pada tahun 2012 naik menjadi 1.540.665 atau naik sekitar 270,3306 ton. Selain itu, Mujahiddin (2016) juga memberikan 
gambaran produksi sampah yang dihasilkan setiap individu perhari yang memberikan konstribusi terhadap pertumbuhan sampah di satu kota. Mujahiddin kemudian memberikan contoh kasus di Kota Jakarta, di mana setiap setiap individu menghasilkan 1 kilogram sampah perhari yang jika dihitung secara keseluruhan maka jumlahnya mencapai 7.000 ton/hari.

Di Kabupaten Deli Serdang, sampah juga menjadi persoalan yang perlu untuk diselesaikan. Menurut Wakil Bupati Deli Serdang Yusuf Siregar, jumlah penduduk yang mencapai 2.155.625 jiwa memberikan dampak pada produksi sampah setiap harinya yang mencapai sekitar 1.078 ton perhari. Untuk itu, menurut Yusuf dibutuhkan perubahan cara pandangan masyarakat dalam pengelolaan sampah. Sampah harus terpilah sejak dari rumah tangga sehingga akan memudahkan dalam pengelolaannya (Juraidi, 2019). Perubahan cara pandang bagi masyarakat Kabupaten Deli Serdang dalam pengelolaan sampah memang sangat dibutuhkan. Sebab, pada laporan yang dikeluarkan oleh perusahan asal korea HGNS Corporation terlihat bahwa baru 12\% sampah di Kabupaten Deli Serdang yang berhasil diangkut ke Tempat Pembuangan Akhir (TPA) dan sisanya sebanyak 88\% sampah ditumpuk sembarangan (Ariyanti, 2019).

Padahal jika sampah-sampah yang dihasilkan oleh masyrakat khususnya yang dihasilkan dari skala rumah tangga dikelola dengan cara daur ulang tentu akan menghasilkan nilai ekonomi yang dapat menjadi sumber penghasilan tambahan bagi keluarga. Untuk itu, agar sampah dapat menghasilkan nilai ekonomi maka daur ulang sampah rumah tangga yang bersifat organik dan anorganik harus dilakukan dengan mengubah sampah menjadi materi barang berguna, seperti sampah organik dapat diubah menjadi pupuk kompos dan sampah anorganik dapat diubuah menjadi barang kreasi atau aksesoris. Melalui daur ulang sampah ini, menurut Utami (2013) dapat mendorong masyarakat untuk memisahkan dan mengkelompokkan sampah sehingga terbentuk satu tatanan atau sistem pengelolaan sampah yang lebih baik di masyarakat. Apa yang dikatakan oleh Utami tersebut, dibenarkan oleh Mujahiddin \& Ananda (2017) yang pada hasil penelitian mereka di Sicanang Belawan Medan menemukan bahwa masyarakat yang berhasil mendaur ulang sampah-sampah rumah tangganya mendapatkan manfaat secara ekonomi, yaitu dengan menjual sampah-sampah anorganik yang telah didaur ulang menjadi aksesoris dan hasil penjualan tersebut dapat membantu memenuhi belanja pangan keluarga seperti; membeli gula, beras dan minyak goreng. Tidak hanya itu, beberap hasil penelitian dan pengabdian masyarakat terdahulu juga menunjukkan hal yang sama, yaitu pengelolaan sampah yang dilakukan melalui daur ulang sampah sangat membantu masyarakat dalam menambah pendapatan (Riswan, 2011; Linda, 2016; Arico \& Sri, 2017; Syaputra, 2018; Suryani dkk, 2019) dan juga memberikan efek terhadap pemberdayaan serta peningkatan keterampilan bagi masyarakat (Asteria \& Heru, 2016; Hernawati dkk, 2013; Mujahiddin dkk, 2018; Sari dkk, 2018).

Secara umum, pelaksanaan PKM ini akan dilaksanakan di Desa Pematang Johar. Pilihan terhadap desa ini dikerenakan aktifitas pengelolaan sampah di Desa Pematang Johar masih menggunakan sistem Kumpul-Angkut-Buang. Di mana sampah yang telah diangkut akan dibuang pada Tempat Pembungan Sementara (TPS) yang berada di Desa Pematang Johar dengan luas lahan 0,08 Hektar. Selain itu, masih terdapat warga masyarakat yang mengelola sampah dengan cara membakar tumpukan sampah (baik sampah organik dan anoragnik) yang ada dipekarangan rumah mereka. Dengan jumlah penduduk 14.807 jiwa tentu potensi sampah per-hari yang ada di Desa Pematang Johar cukup menjanjikan untuk diolah secara ekonomis agar menjadi satu produk yang terbaharukan. Oleh karenanya, pengelolaan sampah dengan pendekatan 3R (Reduce, Reuse dan Recycle) patut untuk diterapkan di Desa Pematang Johar agar mampu mendorong masyarakat untuk berperan aktif di dalam pengelolaan sampah rumah tangga mereka. Oleh karena itu, Program Kemitraan Masyarakat (PKM) ini akan dilaksanakan dengan memberikan pelatihan pengelolaan sampah kepada perwakilan masyarakat yang ada di Desa Pematang Johar -yang ditujukan kepada kelompok PKK Desa dan juga pengurus BUMDes -dengan harapan kelompok-kelompok tersebut dapat menjadi agen perubahan dengan memberikan pengetahuan tentang pengelolaan sampah kepada masyarakat lainnya di Desa Pematang Johar. Sehingga, nantinya sampah-sampah yang ada pada skala rumah tangga di Desa Pematang Johr dapat menjadi produk-produk olahan yang dapat digunakan atau dipasarkan dan bernilai ekonomis. 
Hasilnya, sampah-sampah pada skala rumah tangga diharapkan dapat menjadi produkproduk olahan yang dapat digunakan kembali dan bernilai ekonomis. Untuk sampah rumah tangga dengan jenis organik misalnya dapat menjadi pupuk organik padat (kompos), pupuk organik cair (POC), dan mikro organisme lokal (MOL). Sedangkan untuk jenis sampah anorganik, hasil daur ulangnya diharapkan dapat menghasilkan berbagai aksesoris seperti; tas, dompet, hiasan dinding, alas meja, pot bunga dan aksesoris lainnya yang dapat dijadikan hiasan atau dapat dijual melalui berbagai kegiatan promosi pada pameran lingkungan.

Di sisi lain, Desa Pematang Johar juga memiliki potensi dan peluang dalam pengelolaan sampah skala rumah tangga. Hal ini dikarenakan adanya komitment Pemerintahan Desa Pematang Johar dalam pelaksanaan pemberdayaan masyarakat. Setidaknya ada berbagai kelompok pemberdayaan masyarakat yang telah dibentuk oleh pemerintah desa dan berhasil berjalan dengan menghasilkan berbagai produk olahan seperti; adanya kelompok pembantik yang menghasilkan batik sawah, kelompok pengerajin sisa kulit kerang yang menghasilkan akseoris dari kulit kerang, kelompok peternak bebek petelur yang menghasilkan telur bebek, dan kelompok pengeraji tempe yang menghasilkan tempe. Selain itu, di Desa Pematang Johar, kelompok Pemberdayaan Kesejahteraan Keluarga (PKK) dan Pengurus BUMDes yang sangat aktif dalam membantu berbagai program pemberdayaan masyarakat di desa. Sehingga nantinya, pelaksanaan PKM di Desa Pematang Johar akan difokuskan pada Kelompok PKK dan juga Pengurus BUMDes yang diharapkan dapat menjadi penggerak dalam kampaye pengelolaan sampah skala rumah tangga di Desa Pematang Johar. Atas seluruh penjabaran tersebut maka PKM ini mengangkat judul: Pelatihan Pengelolaan Sampah Rumah Tangga Bagi Kelompok PKK dan Pengurus BUMDes Di Desa Pematang Johar, Kabupaten Deli Serdang.

\section{METODE}

Metode pada kegiatan PKM ini dilaksanakan dengan dua pendekatan yaitu; sosialisasi, pelatihan dan Focus Group Discussion (FGD). Adapun penerapan dari kedua pendekatan tersebut sebagai berikut:

1. Pendekatan Sosialisasi: pendekatan ini dilakukan untuk memberikan pemahaman dan pengetahuan kepada masyarakat tentang pentingnya pengelolaan sampah skala rumah tangga secara mandiri dengan menggunakan prinsip 3R dan manfaat yang dihasilkan dari pengelolaan sampah tersebut, baik secara sosial-ekonomi dan juga lingkungan.

2. Pendekatan Pelatihan: pendekatan pelatihan ini dilaksanakan untuk memberikan peningkatan keterampilan kelompok masyarakat di Desa Pematang Johar dalam mengelola sampah rumah tangga yang berjenis organik dan anorganik. Adapun bentuk pelatihan yang dilakukan sebagai berikut:

2.1 Pelatihan pengelolaan sampah rumah tangga berjenis organik diarahkan dengan mendaur ulang sampah sisa makanan menjadi pupuk kompos dengan metode kompester.

2.2. Pelatihan pengelolaan sampah rumah tangga dengan jenis anorganik diarahkan dengan mendaur ulang sampah sisa botol atau kain menjadi aksesoris atau barang kreasi yang layak dijual.

3. Focus Group Discussion (FGD): pendekatan ini digunakan untuk mengevaluasi hasil dari pelaksanaan sosialisasi dan pelatihan yang terkait dengan pengelolaan sampah rumah tangga di Desa Pematang Johar. Melalui FGD ini akan terlihat peningkatan-peningkatan apa saja yang dirasakan oleh perwakilan kelompok masyarakat yang telah mengikuti kegiatan sosialisasi dan pelatihan. 


\section{HASIL DAN PEMBAHASAN}

Program Kemitraan Masyarakat (PKM) ini dilaksanakan selama dua hari di Aula Kantor Pemerintahan Desa Pematang Johar, 11-12 Juni 2020 dengan jumlah perserta sebanyak 20 orang yang terdiri dari 10 orang anggota PKK Desa Pematang Johar dan 10 orang lainnya adalah Pengurus BUMDes Desa Pematang Johar. Kegiatan PKM ini diawali dengan pemberian sosialisasi terkait pengutan pemahaman dan pengetahuan masyarakat tentang pentingnya pengelolaan sampah secara mandiri pada skala rumah tangga dengan menggunakan prinsip 3-R (Reduce, Reuse, Recycle). Di sini, narasumber menjelaskan bahwa pengelolaan sampah dengan prinsip 3$\mathrm{R}$ sangatlah menguntungkan karena sampah-sampah yang dihasilkan pada skala rumah tangga dapat didaur ulang untuk digunakan kembali dan bahkan dapat dijual untuk menghasilkan uang. Dengan itu maka nilai guna barang yang sudah menjadi sampah dapat ditingkatkan, yang sebelumnya tidak berguna menjadi barang berguna.

Setidaknya terdapat 3 (tiga) manfaat yang bisa diharapkan dari adanya pengelolaan sampah skala rumah tangga dengan menggunakan prinsip 3-R, yaitu: Pertama, manfaat bagi kesehatan lingkungan. Kedua, manfaat secara ekonomi, dan Ketiga, manfaat pendidikan lingkungan. Untuk manfaat kesehatan lingkungan, pengelolaan sampah dengan prinsip 3-R diharapkan mampu menciptakan lingkungan yang bersih dan sehat, mengurangi kebiasaan membakar sampah dan menimbun sampah. Sedangkan untuk manfaat ekonomi, pengelolaan sampah dengan prinsip 3R diharapkan dapat menambah penghasilan keluarga. Untuk aspek pendidikan, pengelolaan sampah dengan prinsip 3R diharapkan dapat mengubah kebiasan masyarakat dalam mengelola sampah yang dihasilkannya. Masyarakat diharapkan sudah mampu untuk memilah sampah, mengubahnya menjadi barang berguna dan memakainya atau mendisrtribusikannya secara ekonomi.

Usai mendapatkan pemahaman tentang tentang pentingnya pengelolaan sampah secara mandiri pada skala rumah tangga dengan menggunakan prinsip 3-R, peserta PKM yang terdiri dari anggota PKK dan Pengurus BUMDes Desa Pematang Johar selanjutnya dilatih untuk dapat mengelola sampah organik yang dihasilkan dari rumah tangga menjadi pupuk kompos dengan metode kompester. yaitu suatu metode pengelolaan sampah organik menjadi kompos untuk digunakan sebagai pupuk. Metode komposter ini sederhana, yaitu memanfaatkan kerja bakteri untuk mengurai sampah. Pada tahapan awal, narasumber atau pemateri meminta peserta khususnya kelompok perempuan yang telah membawa sampah organiknya untuk memotong, mencincang atau menghaluskan sampah tersebut sebelum dicampurkan pada dedak dan skam padi yang telah disediakan (Lihat Gambar 1).

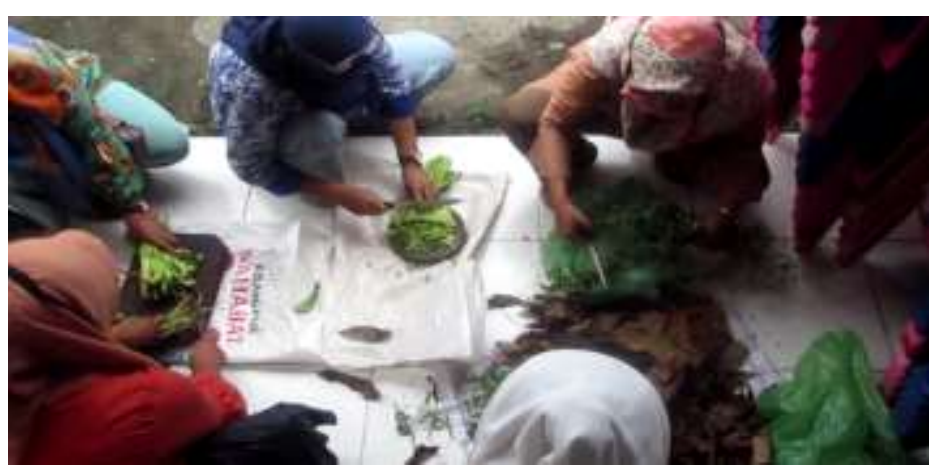

Gambar 1. Peserta PKM Memotong Sampah Organik

Sambil menunggu sampah-sampah organik tersebut dipotong dan dihaluskan, kelompok laki-laki diminta untuk mancampurkan sekam dan dedak padi dengan Mikro Organisme Lokal (MOL) atau disebut juga pupuk cair yang telah disediakan. Sebelum MOL dicampurkan dengan sekam, terlebih dahulu MOL -sebanyak 4 tutup botol - dilarutkan ke dalam air. Air yang telah bercampur dengan MOL kemudian disiram di atas permukaan dedak dan sekam, lalu diaduk hingga merata (Lihat Gambar 2). Agar tidak memakan waktu dalam PKM ini, pihak narasumber atau instruktur telah menyediakan MOL untuk campuran dalam pembuatan pupuk kompos dari 
sampah organik. Begitupun, narasumber tetap menjelaskan proses pembuatan MOL dengan metode 3, 1, 10. Yaitu $3 \mathrm{Kg}$ buahan-buahan atau sayur-sayuran busuk, $1 \mathrm{Kg}$ gula aren atau $1 \mathrm{Liter}$ tetes tebu dan 10 Liter Air. Semua bahan dimasukan menjadi satu dan di fregmentasi selama 40 hari. Menurut narasumber, semakin lama proses fregmentasi maka semakin bagus.
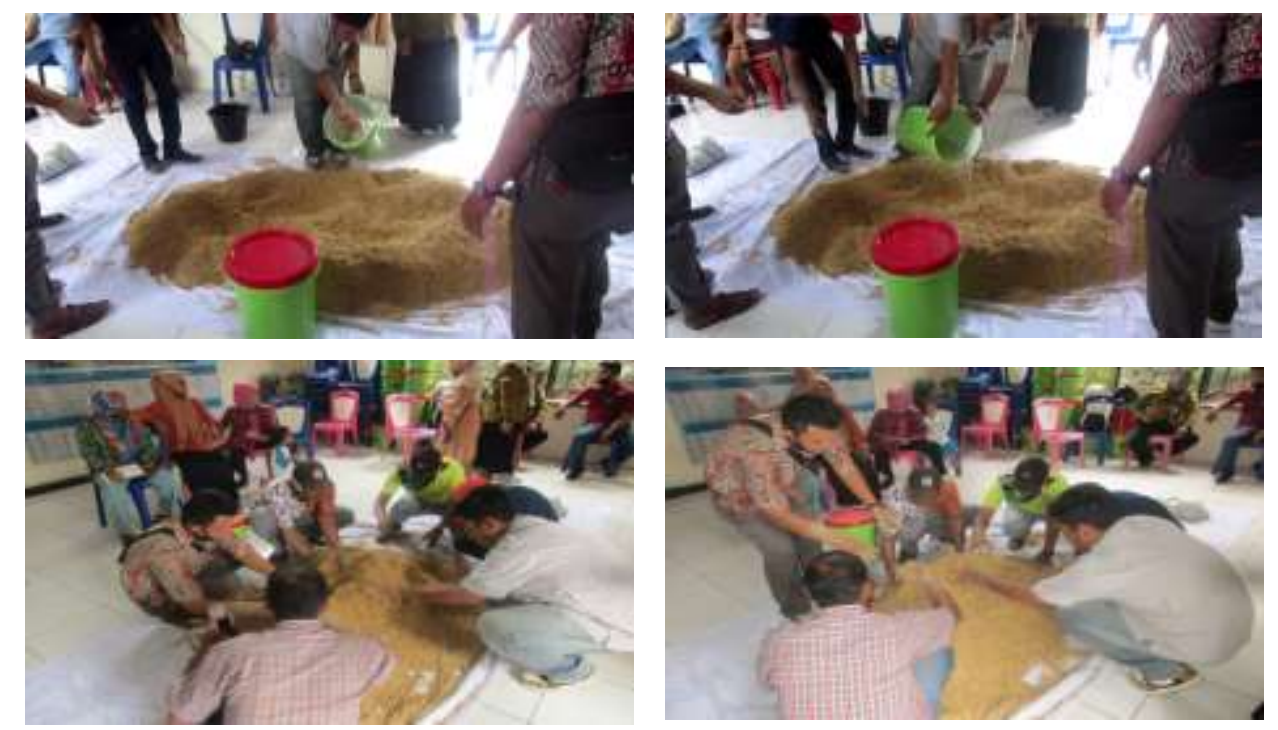

Gambar 2. Peserta PKM Mencampurkan MOL dengan Sekam dan Dedak

Tanda MOL sudah merata secara keseluruhan pada sekam dan dedak dapat dilihat dari basahnya semua permukaan sekam dan dedak. Di sini, narasumber juga menjelaskan tingkat kebasahan sekam dan dedak juga harus diperhatikan, jangan sampai ketika sekam dan dedak diperas mengeluarkan air, itu tandanya terlalu basah dan tidak baik untuk proses pemupukan. Setelah itu, sampah-sampah organik yang telah dipotong-potong tersebut dicampurkan pada dedak dan sekam yang telah basah tadi secara merata (Lihat Gambar 3). Setelah tercampur, maka biarkan sampah tersebut selama 10 hari di dalam keranjang atau kain goni. Selama 10 hari akan terjadi proses fregmentasi sehingga sampah tersebut berubah menjadi pupuk kompos.

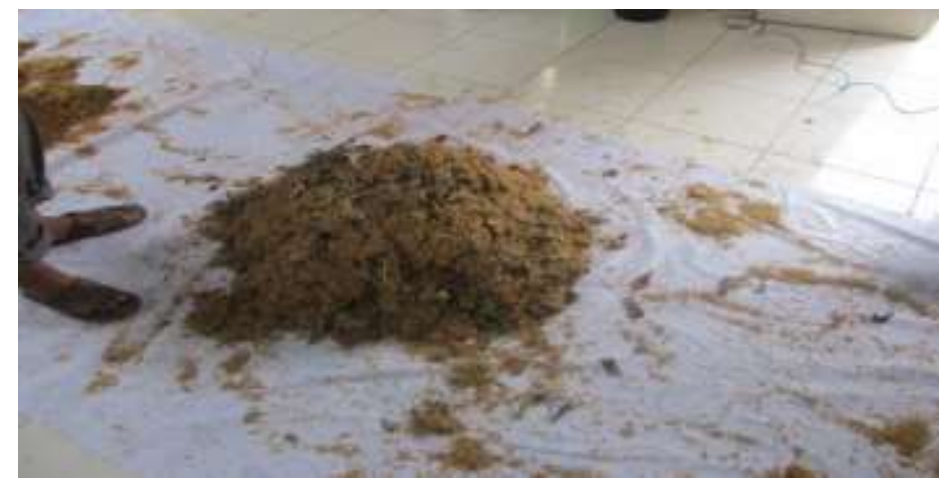

Gambar 3. Sampah Organik Yang Telah Dicampurkan Pada Sekam dan Dedak

Hari berikutnya, tepatnya pada tangga 12 Juni 2020, Tim PKM memberikan penguatan keterampilan bagi Kelompok PPK dan Pengurus BUMDes di Desa Pematang Johar dalam mengelola sampah anorganik melalui pelatihan kreasi daur ulang. Adapun sampah anorganik yang digunakan adalah: Pipa karton sisa gulungan karpet dan kain goni serta beberapa potongan kardus. Adapun peralatan yang digunakan untuk membuat aksesoris tersebut adalah: Lem tembak, gunting dan pisau serta beberapa pita untuk mempercantik hasil kreasi (Lihat Gambar 
4). Hasil dari pelatihan kreasi ini, setiap peserta berhasil membuat satu celengan dari bahanbahan sampah anorganik yang disebutkan di atas (Lihat Gambar 5).
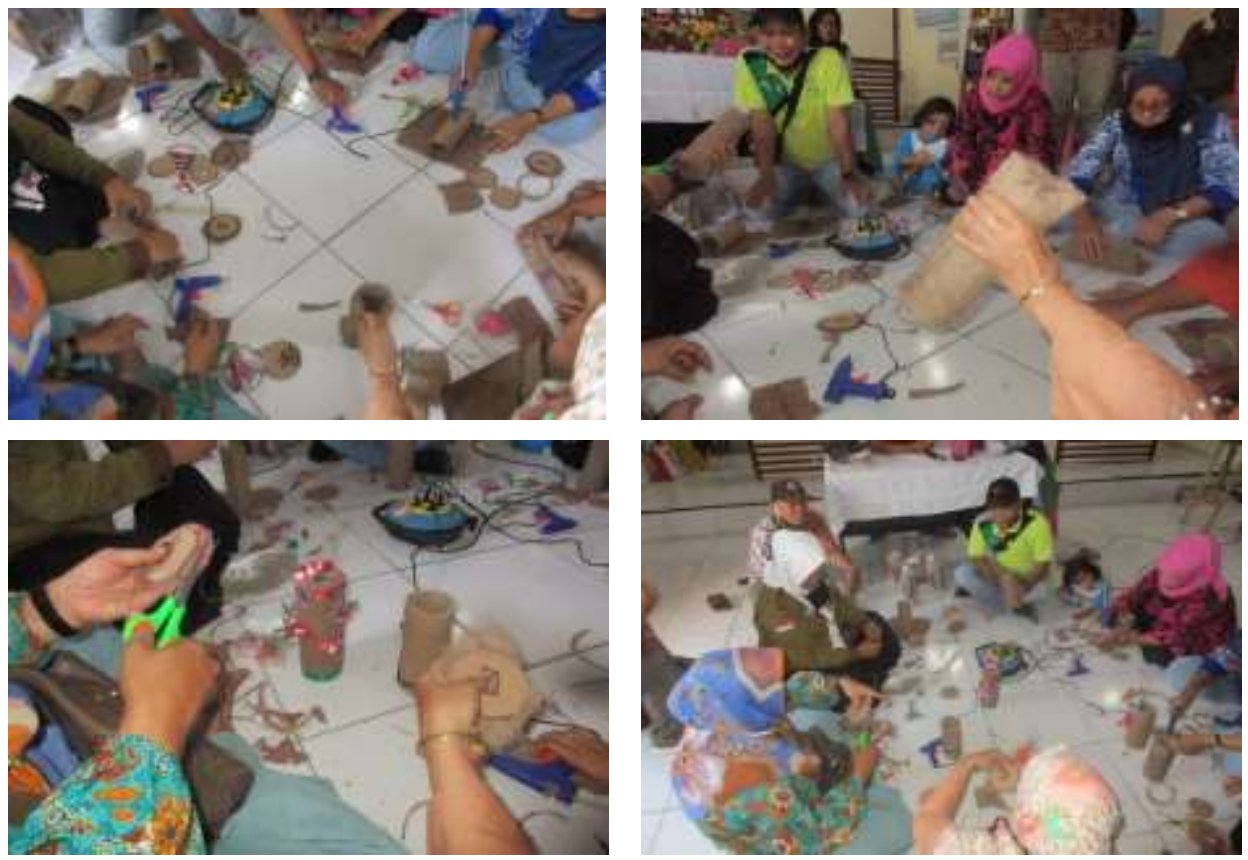

Gambar 4. Proses Daur Ulang Sampah Anorganik Menjadi Barang Kreasi
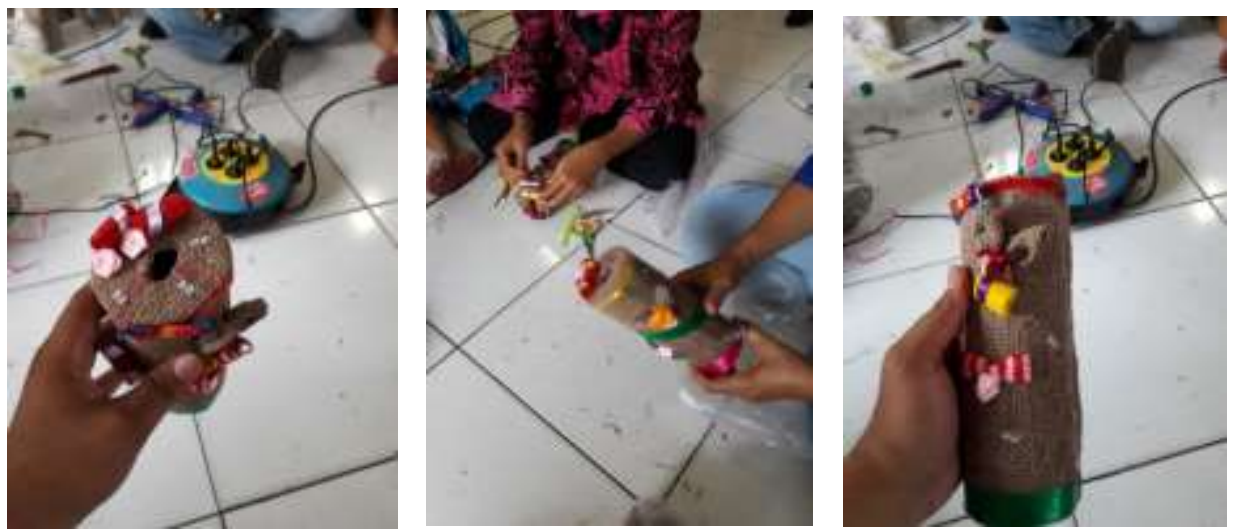

Gambar 5. Celengan Hasil Daur Ulang Sampah Anorganik

Melalui pelatihan ini peserta secara langsung diajarkan mengelola sampah anorganik menjadi barang kreasi yang berguna. Menurut narasumber atau instruktur pelatihan, barangbarang kreasi seperti celengan ini dapat dijual dengan harga yang lumayan menguntungkan, yakni Rp. 30.000,- sampai dengan Rp. 50.000,-. Selain itu, narasumber juga mengatakan kepada peserta pelatihan bahwa setiap sampah anorganik yang dihasilkan pada skala rumah tangga dapat didaur ulang menjadi barang kreasi yang menjanjikan, asalkan peserta punya kemauan untuk merubahnya dan menghiasnya. Oleh karenanya, penting untuk menimbulkan jiwa kreatif dan inovatif di dalam diri, agar benda-benda yang tidak berguna dapat diolah kembali. Narasumber memberikan contoh, misalnya; kardus yang tidak terpakai, jika dipola dengan tepat, bisa dijadikan kotak tisu.

Terakhir, setelah seluruh rangkaian sosialisasi dan pelatihan selesai, Tim PKM melaksanakan FGD dengan seluruh peserta yang mengikuti sosialisasi dan pelatihan. Hasilnya, seluruh peserta memahami dan mengetahui bagaimana pelaksanaan pengelolaan sampah skala 
rumah tangga dengan menggunakan prinsip 3-R. Seorang peserta yang bernama Nurhayati mengatakan setelah selesai mengikuti pelatihan ini akan menerapkan daur ulang sampah organik di rumahnya. Hal ini dikarenakan hasil pengelolaan sampah organik dapat menjadi pupuk kompos yang bisa digunakannya sebagai media tanam.

\begin{abstract}
"Setelah ini saya akan membuat pupuk kompos dari sampah sisa dapur saya. Karena di halaman rumah saya suka menanam bunga. Jadi saya tidak payah untuk membeli pupuk lagi, bisa saya dapatkan dari sampah saya sendiri." (Hasil FGD dengan Nurhayati, Warga Dusun IX Desa Pematang Johar)
\end{abstract}

Selain Nurhayati, keinginan untuk melakukan praktik daur ulang sampah skala rumah tangga juga datang dari Sumariono yang mengatakan akan melakukan praktik daur ulang sampah plastik di sekitaran lingkungan rumahnya. Menurutnya, setelah mendapatkan pengetahuan dari sosialisasi PKM ini, pikirannya semakin terbuka terkait bahaya sampah plastik bagi lingkungan. Selama ini, Sumariono mengatakan telah melakukan kegiatan ecobrick bersama anak-anak pengajiannya di Desa Pematang Johar.
"Selama ini saya sudah laksanakan kegiatan ecobrick. Tapi seteah adanya PKM ini, minat saya untuk terus melanjutkan dan mengajarkan praktik ecobrick terhadap anak-anak pengajian saya semakin kuat. Saya rasa kesadaran dan gerakan pengelolaan sampah khususnya plastik harus terus dilakukan." (Hasil FGD dengan Sumariono, Warga Dusun XV Desa Pematang Johar)

Dengan demikian, secara keseluruhan, pelaksanaan PKM di Desa Pemaang Johar Kabupaten Deli Serdang menunjukkan adanya peningkatan kemampuan Kelompok PKK dan Pengurus BUMDes dalam mengelola sampah skala rumah tangga baik yang berjenis organik dan anorganik. Peningkatan kemampuan ini dapat dilihat dari adanya produk daur ulang sampah yang dihasilkan oleh kedua kelompok ini yaitu pupuk kompos dari sampah organik dan kreasi celengan dari daur ulang sampah anorganik.

\title{
4. KESIMPULAN
}

Berdasarkan hasil pelaksanaan Program Kemitraan Masyarakat (PKM) di atas terlihat bahwa: Kelompok masyarakat Desa Pematang Johar yang terdiri dari Kelompok PKK dan Kelompok Pengurus BUMDes telah memahami praktik pengelolaan sampah skala rumah tangga dengan menggunakan Prinsip 3-R (Reduce, Reuse, Recycle). Selain itu, kelompok masyarakat Desa Pematang Johar telah memahami dan mampu mempraktikkan pengelolaan sampah organik menjadi pupuk kompos melalui metode komposter. Kelompok masyarakat Desa Pematang Johar juga telah memahami dan mampu mempraktikkan pengelolaan sampah anorganik menjadi barang kreasi seperti celengan. Dengan hasil yang didapatkan tersebut maka Tim PKM menghibau Pemerintah Desa Pematang Johar dan kelompok masyarakat yang terlibat untuk dapat membentuk kelompok pengelolaan sampah rumah tangga di desa, yang bisa diimplementasikkan dalam bentuk Bank Sampah sehingga sampah-sampah yang dihasilkan setiap keluarga pada skala rumah tangga menjadi lebih berharga secara ekonomi.

\section{UCAPAN TERIMA KASIH}

Penulis dan seluruh Tim PKM mengucapkan terima kasih kepada Universitas Muhammadiyah Sumatera Utara yang telah memberikan dukungan financial terhadap kegiatan PKM yang mengakat tema Pelatihan Pengelolaan Sampah Rumah Tangga Bagi Kelompok PKK dan Pengurus BUMDes di Desa Pematang Johar Kabupaten Deli Serdang dengan Tahun Anggaran 2019. Selain itu, penulis juga mengucapkan terimakasih kepada mitra PKM yaitu; Kelompok PKK 
Desa Pematang Johar dan BUMDes Desa Pematang Johar Kabupaten Deli Serdang yang telah memberikan kerja sama yang baik sehingga PKM ini dapat terlaksana dengan baik.

\section{DAFTAR PUSTAKA}

Arico, Z., \& Sri., J. (2017). Pengolahan Limbah Plastik Menjadi Produk Kreatif Sebagai Peningkatan Ekonomi Masyarakat Pesisir. Martabe: Jurnal Pengabdian Masyarakat. 1(1), 1-6.

Ariyanti, Duwi Setiya. (2019, April 05). Perilaku Masyarakat, 88\% Sampah di Deliserdang Dibuang Sembarangan. Bisnis.com. Diambil dari: https://sumatra.bisnis.com/read/20190405/533/908397/perilaku-masyarakat-88sampah-di-deliserdang-dibuang-sembarangan

Asteria, D., \& Heru, H. (2016). Bank Sampah Sebagai Alternatif Strategi Pengelolaan Sampah Berbasis Masyarakat di Tasikmalaya. Jurnal Manusia dan Lingkungan. 23(1), 136-141.

CNN Indonesia. (2018, Januari 22). Kala Sampah Jadi Uang di Bandung. www.cnnindonesia.com. Diambil dari: https://www.cnnindonesia.com/gaya-hidup/20180122132513-282270681/kala-sampah-jadi-uang-di-bandung

Juraidi. (2019, November 11). Deliserdang Hasilkan Sampah 1.078 Ton Setiap Hari. Antaranews.com. Diambil dari: https://today.line.me/id/pc/article/Deliserdang+Hasilkan+Sampah+1+078+Ton+Setiap+Ha ri-Q9NyBz

Linda, R. (2016). Pemberdayaan Ekonomi Kreatif Melalui Daur Ulang Sampah Plastik (Studi Kasus Bank Sampah Berlian Kelurahan Tangkerang Labuai). Jurnal Al-Iqtishad. 12(1), 1-19.

Mujahiddin (2014). Upaya Pemberdayaan Masyarakat Dalam Mengelola Sampah Anorganik Melalui Bank Sampah Studi Kasus di Bank Sampah Simpan Jadi Emas Lingkungan V Blok B Lorong II Kelurahan Belawan Sicanang Kecamatan Medan Belawan. Thesis. Medan: Magister Studi Pembangunan Fakultas Ilmu Sosial Ilmu Politik Universitas Sumatera Utara.

Mujahiddin (2016). Upaya Pemberdayaan Masyarakat Dalam Mengelola Sampah. Medan: n'Basis. Mujahiddin \& Ananda, M. (2017). The Benefit of Waste Bank for Poor Families in Sicanang Belawan, Medan, North Sumatra. Journal of Humanities and Social Science. 22(3), 37-43.

Mujahiddin,. Yurisna, T., Efendi, A. (2018). Analysis of the Effect of Waste Bank Program on Empowerment of Poor Women in Kelurahan Sicanang Belawan Medan. 1(3), 105-113.

Riswan,. Henna, R, S,. \& Agus H. (2011). Pengelolaan Sampah Rumah Tangga Di Kecamatan Daha Selatan. Jurnal Ilmu Lingkungan. 9(1), 31-39

Sari, M,. Sri, U. T., \& Raudhah, A. (2018). Peningkatan Keterampilan Mahasiswa Dalam Pengelolaan Sampah Organik Untuk Mewujudkan Green Campus di Universitas Lancang Kuning. Jurnal Pengabdian Kepada Masyarakat. 2(2), 193-196.

Sulistya, Rahma. (2019, Juli 17). Sampah Indonesia Terus Meningkat Tiga Juta Ton Tiap Tahun. republika.co.id. Diambil dari: https://nasional.republika.co.id/berita/pus5ex368/sampahindonesia-terus-meningkat-tiga-juta-ton-tiap-tahun

Suryani, L., Ariswan, U. A., \& Kristianus, J. T. (2019). PKM Pelatihan Kelompok Anak Cinta Lingkungan Kabupaten Ende Dalam Pengelolaan Limbah Organik Dan Anorganik Berbasis 3R Untuk Mengeskalasi Nilai Ekonomi Barang Sebagai Bekal Wirausaha Mandiri. 3(2), 244-251.

Syahputra, A. (2018). Peran Pemerintah Kecamatan Medan Deli Dalam Meningkatkan Perekonomian Masyarakat dan Ibu Rumah Tangga Dalam Pengelolaaan Bank Sampah di Kecamatan Medan Deli. Jurnal Publik Reform. IV(4), 77-84.

Undang-Undang Republik Indonesia No18 Tahun 2008 Tentang Pengelolaan Sampah.

Utami, Eka. (2013). Buku Panduan Sistem Bank Sampah \& 10 Kisah Sukse. Jakarta: Yayasan Unilever Indonesia. 